\title{
An Assessment of Significance of Value Stream Mapping to Mitigate Challenges Related to Solid Waste Management: Insights from Literature
}

\author{
Anne Miya \\ Ph. D Student, Department of Management science, \\ School of Business and Economics, Kisii University, Kenya

\section{Christopher Ngacho} \\ Senior Lecturer, Department of Management and Economics, \\ School of Business and Economics, Kisii University, Kenya
}

Doi: $10.1515 / m j s s-2017-0022$

\begin{abstract}
Solid waste management (SWM) is defined as the process of collecting, treating, storing and disposal of solid waste in a way that they are harmless to humans, animals, plants and the general environment. In Kenyan cities, solid waste is disposed in open dump system which is uncontrolled thereby posing numerous challenges to public health and environment. The purpose of this present is to identify challenges to SWM globally as reported in various literature and how value stream mapping (VSM) can be applied to mitigate the challenges. The study is based on the following challenges to SWM; composition of solid waste, physical and technical infrastructure, policy legislation and enforcement, personnel, funding and community's attitude to SWM in relation to the following VSM components; 1. Consumer, 2. Supplier, 3. Materials flow and 4. Information flow. The cities are strategic centers of aesthetic value, peace and security which have been overtaken by messy unattended heaps of solid waste emanating from domestic sources, markets, business and shopping centers. Identification of waste management challenges in developing countries is critical to also help select the most appropriate technology for waste management to avoid blind transport of technology and machinery from developed countries which most fail.
\end{abstract}

Keywords: Solid Waste; Management; Challenges; Value Stream Mapping

\section{Introduction}

\subsection{Solid waste management and challenges to solid waste management.}

One of the most burdens that cause health and environment problems facing African countries is SWM even though these cities use $20-50 \%$ of budget allocated to SWM, the waste collected is only $20-80 \%$. The illegally dumped uncontrolled waste constitute a disaster for human health and environmental degradation. Inefficient solid waste collection and lack of disposal facilities are the most common problems in developing countries. Researchers have identified several factors to work against SWM efforts in developing countries. The identified common constraints include; inappropriate technology, inefficient policy enforcement, illegal dumping, lack of trained human resource, lack of financing, lack of legislation, lack of political support, policy conflict and overlapping responsibilities at different levels in government, rapid increase of waste generation 
with limited data, limited land space, land tenure issues and lack of awareness among the public. Municipal officials and waste contractors seem unable to combat unlawful and illegal dumping of solid waste on the streets and drainages. The most affected by bad sanitation are the rural poor and residents of slums in fast growing regions mostly Asia and Africa (Alexander et al., 2014). Agwu, (2012) reported that developed countries are less affected with SWM practices than developing countries. In recent years' policies and legislations were passed by European union (EU) and implemented in UK to help mitigate the challenges of solid waste management in the country. Those legislations included; waste incineration directive 2000/76/EC, waste landfill directive 99/31/EC, the packing waste directive 94/62/EC and waste electrical and electronic equipment directive 2002/96/EC. For instance, the waste landfill directive set the target for decreasing biodegradable materials that end up in landfill to $75 \%$ of 1995 levels by $2006,50 \%$ of 1995 levels by 2009 and 35\% of 1995 levels by 2016 . Directive for incineration set strict conditions that included technical requirements and emission limit values to achieve overall high level environmental and human health protection. The package waste directive aimed at preventing production of packaging waste and encouraged its recycling, recovery and reuse. Waste electrical and electronic equipment directive aimed at promoting reuse, recovery and recycling of electrical and electronic waste to reduce amount of solid waste produced.

Nabegu (2010) reported that in Nigeria, several tons of municipal solid waste are left on the streets each day uncollected thereby clogging drains, causing infrastructural problems, creating feeding grounds for pests which spread diseases and other health related problems. A study in Tanzania attributed SWM problems to include scarcity of finance, human technical and physical resources. In Kampala Uganda, researches identified causes to waste management to include lack of dumping sites, inefficient collection methods, ignorance of masses about need for proper waste disposal, poor attitude of government towards SWM, corruption among public officials, poverty and lack of trained personnel on SWM (Alexander et al., 2014). In Kenya, Okot- Okumu (2012) reported that national priorities differ from local environmental management activities causing low remissions for SWM. Funds for the operation are mainly from external sources (over 50\%) which makes the central government not adequately cost-evaluate decentralized environmental functions. Policy is largely the responsibility of the central government but implementation and legislation is devolved to local government which has led to inadequate policy and legislation.

\subsection{Value Stream Mapping}

Lean thinking philosophy is an approach that was developed and used in Toyota Production System. It has gained significant popularity in the last decades because of its ability to identify and eliminate non-value adding activities that are cost incurring. The US Environmental Protection Agency advised the integration of lean implementation to improve environmental performance. They defined environmental wastes as any unnecessary use of resources and any substance released on land, water and air that could harm human health or the environment. Lean philosophy proposes five lean principles that ought to be deployed to ensure success and sustainable performance towards delivery of goods or services. These principles include; 1 . Definition of value from a customer perspective, 2 . Identify the entire value stream and eliminate waste, 3 . Make value flow, 4. Production of good/service in response to customer, 5. Pursuit perfection embedding it into the system (Abreu and Alves, 2015; Martin and Osterlin, 2013). Xiaoqi (2014) reported that VSM is one of the lean thinking techniques that analyzed and designed flow of materials and information to bring a service or product to a customer, improved work strategies, and gave an in-depth understanding of waste elimination and delivery value. He summarized benefits of VSM as follows; 1. A visual unifying tool that can help visualize non visible work such as exchange of information., 2. VSM creates connections with the customer and helps an organization focus more on customer perspective, 3. VSM provides a holistic system view that connects separate parts into a more collaborative organization with specific objectives, 4. VSM helps to visualize and simplify work process at the macro level to help improve strategic decisions, 5. Value stream maps are effective means of orienting newcomers to understand the holistic view of the organization to help them identify where they fit. 
Allan Robinson developed a process improvement service system using $5 \mathrm{~W} 2 \mathrm{H}$ approach. It is a systematic approach that asks certain questions about a process that can lead to cost and waste reduction. The $5 \mathrm{~W} 2 \mathrm{H}$ approach [five questions that begin with $\mathrm{W}$, and two questions that begin with $\mathrm{H}$; as follows; What, Why, Where, When, Who, How, and How much. The following table 1.1 is a value stream map illustration that can be used to systematically reduce waste in a production process and identify opportunities for improvement (Stevenson, 2012).

Table 1.1: A systematic approach to waste reduction

\begin{tabular}{|c|c|c|c|}
\hline Category & $5 \mathrm{~W} 2 \mathrm{H}$ & Typical questions & Goal \\
\hline Subject & What? & What is being done? & Identify the focus of analysis \\
\hline Purpose & Why? & Why is this necessary? & Eliminate unnecessary tasks \\
\hline Location & Where? & $\begin{array}{l}\text { Where is it being done? } \\
\text { Why is it done there? } \\
\text { Would it be better to do it someplace else? }\end{array}$ & Improve the location \\
\hline Sequence & When? & $\begin{array}{l}\text { When is it done? } \\
\text { Would it be better to do it at another time? }\end{array}$ & Improve the sequence \\
\hline People & Who? & $\begin{array}{l}\text { Who is doing it? } \\
\text { Could someone else do it better? }\end{array}$ & Improve the sequence or output \\
\hline Method & How? & $\begin{array}{l}\text { How is it being done? } \\
\text { Is there a better way? }\end{array}$ & Simplify tasks and improve output \\
\hline Cost & How much? & $\begin{array}{l}\text { How much does it cost now? } \\
\text { What would the new cost be? }\end{array}$ & Select an improved method \\
\hline
\end{tabular}

Source: Adopted from Alan Robinson; continuous improvement in operations (Stevenson, 2012).

\subsection{Statement Problem}

Indiscriminate and illegal solid waste disposal is an embarrassment to developing countries where accumulated heaps of refuse litter in the central business district (CBD) and residential parts of the city. Large volumes of solid waste generated are either deposited on road sides, illegal dumpsite, in drainage systems or open sites which have great impact to the environment Kenya included. Inadequate facilities for solid waste, poor funding, inefficient coordination and implementation of policies as well as life styles have contributed to poor SWM in most developing cities. Despite the efforts made and attention towards SWM in terms of collection, processing, treatment, utilization, recycling and disposal, the challenges to SWM have contributed against effective management of waste in developing cities as reviewed in literature. Major challenges include; composition of solid waste, physical and technical infrastructure, policy legislation and enforcement, personnel, funding and community's attitude towards SWM. VSM is one of the techniques tool of lean thinking philosophy that can be used to analyze the current state of a process, materials and information flow necessary to bring out products or services to the customer. VSM tool is concerned with finding the best techniques and solutions to reduce or eliminate waste in a process and identify opportunities for improvement. Emerging technologies give the SWM stakeholders an opportunity to enhance solid waste collection, increase its diversion and recycling to mitigate SWM challenges and optimize environmental performance.

\subsection{Objective to the Study}

This paper intends to sensitize all the stakeholders of SWM the strategic methods to reduce and mitigate challenges to SWM as reviewed in literature. Outline successful approaches cities can employ towards implementation of effective SWM especially in developing countries. The strategies are based on the experiences learned by different cities as reviewed in empirical studies, surveys, literature relevant to SWM and recommendations various organizations and research institutions about challenges to SWM and applicable solutions. 


\subsection{Beneficiaries of the Study}

The study would benefit all the stakeholders of SWM towards decision making and policy implementation to enhance minimum solid waste generation and effective management. Effective SWM systems will address public health, air quality, proper sanitation, poverty reduction and other challenges related to SWM to achieve acceptable global standards for quality life.

The study paper presents reviewed literature on publications about SWM, its challenges and applicable solutions especially through VSM. The reviewed literature wishes to develop an evaluation performance framework based on six SWM challenges namely; composition of solid waste, physical and technical infrastructure, policy legislation and enforcement, personnel, funding and community's attitude to SWM in relation to the following VSM components; 1. Consumer, 2. Supplier, 3. Materials flow and 4. Information flow as identified from reviewed literature. The publications reviewed were on general concepts of SWM, others on lean philosophy application in environmental issues while others were more specific on VSM and SWM. The presented paper is divided into five sections, the first section is introduction that discusses a brief history of SWM, challenges to SWM and a brief discussion on lean thinking philosophy and value stream mapping. Second section research methodology, third section literature review on SWM, its challenges and how VSM can be applied to mitigate challenges to SWM. Also in section three is a theoretical framework table of VSM components and their impacts to SWM challenges with key performing indicators that show attributes on SWM. The fourth section is discussion followed by conclusion.

\section{Research Methodology}

The study methodology employed qualitative design based on literature review on VSM and its relationship to SWM and challenges to SWM. The bibliography reviewed included; journal papers, dissertations and books. Identified papers were from databases for the period between 2008 and 2016. For papers search the study used the following key words; value stream mapping, solid waste management, challenges to SWM and Sustainability in SWM. The selected papers were journals related to SWM, environmental management, eco-efficiency and lean-green. The reviewed papers were literature reviews, empirical investigations, case studies and surveys among others.

\section{Literature Review}

Rubiano et al. (2014) Carried out a study in Colombia on applying VSM on SWM, 'A case of small and medium sized enterprise'(SME). The research assessed application of VSM to improve the SWM in a plastic enterprise unit. The solid waste was generated from production processes which included raw materials, work in process, finished products and packaging returns from industrial wastes. To assess application of VSM in SWM at the SME, the study focused on methodological approach based on value stream. The researchers' conventions and indicators for mapping of the solid waste value stream was based on drawing a VSM of the current state and future state for the SME. The study methodology was based on previous works of VSM with environmental focus. The researchers considered characteristics from both applications of VSM in manufacturing and in SMEs to define flows, conventions, indicators that enabled approach of a robust framework for lean practitioners in SWM. Flows and conventions considered included materials and products through a series of steps in the value stream. The study proposed three flows that included; 1 . Value added materials which included total amount of material consumed and finally incorporated in the finished product. 2. Non-value added material which included the total amount of material consumed and was not finally added to the finished product. 3. Solid waste recovered in sales, repairs, remanufacturing from the non-value added materials. The methodology suggested a six step approach that analyzed the current and future states, then its implementation. Data was collected through several visits to the Plastic sector unit (PSU) where processes and flows were observed. Clear actions were then defined on reuse and recycle internally or externally. Findings revealed by the current state showed it was possible to identify the flows of materials, information involved and amount of solid waste generated and managed inside or outside the company. With the application 
of the analysis tool, findings identified 3 solid waste flows; the flow that didn't add value, the flow that originated from the customers revealed weaknesses in quality and failures in recovery strategy, the third flow handled by hydraulic machines showed contamination therefore not suitable for recovery. Table 1.2 shows expected results after application of the proposed VSM methodology.

Table 1.2: Expected results after application of proposed VSM methodology

\begin{tabular}{lcc}
\hline Indicators & Current state of value stream & Future state of the value stream \\
\hline Material adding value & $94 \%$ & $94 \%$ \\
\hline Material not adding value & $6 \%$ & $6 \%$ \\
\hline SW recovered & $0 \%$ & $98 \%$ (from the $6 \%$ ) \\
\hline
\end{tabular}

Source: Rubiano et al. (2014)

Strategies were suggested to improve the environmental performance of SWM. The suggested strategies included; 1. Resource optimization and minimizing the amount of waste produced, 2. Reuse of scrap material by incorporating in the manufacturing line. 3. Improved quality control and process monitoring that ensured number of rejected batches were kept at a minimum and 4 . Waste exchange, where waste product of one process became the raw material for the second process to reduce disposal volumes. The study conclusion validated the use of VSM technique as an approach that would significantly improve the SWM. Further recommendations suggested that future studies on VSM of SWM should consider other uses of solid waste to come up with recovery models as a strategy to reduce costs, gain earnings and mitigate negative environmental effects.

Guerrero et al. (2013) carried out a study to determine the stakeholders action and behavior in their role in waste management and analyzed influential factors on the system. The study was to assess and address challenges of SWM in developing cities. The study aimed to address why there was increased generation of waste, the burden of budget posed by SWM to municipalities, lack of understanding to the diversity of factors that affected different stages of SWM and linkages necessary to enable handling of the entire system. The target population was more than 30 urban areas in 22 developing countries in 4 continents. A combination of methods was used to assess the stakeholders to establish factors influencing performance of waste management in the cities. Data was collected from relevant articles on SWM, observation during visits, structured interviews with relevant professionals, exercises were provided to participants in workshops and questionnaire applied to stakeholders. Analysis of data was by SPSS applying descriptive and inferential statistics. Findings indicated that participants recognized local authority, some ministries from central government and private contractors to be the service providers. The national and local governments were acknowledged as the most important stakeholders that set up policies to SWM. The unrecognized were the informal stakeholders who collected wastes from door to door, from shopkeepers and streets to disposal sites, even though their contribution was seen as very important. Findings revealed limited knowledge on technologies and good practice for waste management, lack of equipment for collection and absence of decision makers interested in environmental programs. Infrastructure which included the roads, increased equipment and human resources had positive impact on delivery of service. It was noted that collection, transfer and transport were very important but also very expensive. Findings showed that composting was relatively low across the cities due to lack of infrastructure and municipal inefficiencies. In final disposal, the study reported that most cities studied had open dumps without leachate treatment, protection nor other infrastructure needed. On recycling, the study noted that when citizens received information and benefits about recycling, they participated more in designing the programs and participate in recycling campaigns. It was also found that when leaders were interested and gave priority in waste management issues, they were more likely to support strategies and infrastructure in waste management. The researchers suggested that decision making and set up programs depended on stakeholders' knowledge and familiarity with new and appropriate technologies as well as good practices on waste management.

A study was carried out by Benefit et al. (2014) in Nigeria on impact of inadequate urban 
planning on municipal SWM. The aim of the research was to investigate the relationship between unplanned urban settlements and inadequate waste management. The study looked into the impacts of inadequate implementation of urban planning of towns and cities to SWM. The methodology used was qualitative and quantitative designs. Data was collected through field surveys, questionnaires, observation and through information got from published materials. Target population was staff of ministry of environment and households within the cities. 1250 questionnaires were distributed of which 800 were retrieved back. Quantitative data was analyzed by chi-square to measure the statistical significance between inadequate planning and municipal SWM. Study findings revealed that some of the indiscriminate waste disposal existed due to unplanned settlements with $21 \%$ of respondents concurring with it. Absence of paved roads and good road network was identified to be a factor that hindered waste collection and disposal services as well as inadequate trained personnel and inadequate funding. The study findings showed that there was strong relationship between unplanned settlements and indiscriminate waste disposal. The study concluded that due to unplanned settlements with badly paved roads, poor road networks and absence of waste management facilities, these factors hindered waste management agencies and companies to collect, transport and dispose generated wastes adequately. To ensure success of SWM in the region, the study reported that good paved roads and networks linking all the settlements in the city was mandatory. Waste management processes, infrastructure and equipment be adequately funded. All stakeholders including the community be part of solid waste planning processes to steer any positive SWM campaign programs.

A study was carried out by Nabegu (2010) in Kano, Nigeria on 'An analysis of municipal solid waste'. The aim of the study was to establish and provide data of waste composition, sources of municipal waste, understand type of waste generated, its flow and their implications for management. The methodology used was quantitative and qualitative designs. Data was collected by field surveys, interviews with stakeholders and secondary data from government agencies. The researcher also participated in the daily waste management operations to record firsthand experience and operational difficulties in SWM. Analysis of waste type showed that $43 \%$ was organic and $57 \%$ non-organic waste. The bio-degradable waste could effectively be diverted from dumpsites and landfills and be utilized through appropriate technologies to process bio-fertilizers and green energy to reduce the bulk waste for disposal. However, composition of waste reported human faecal matter which had environmental impacts and public health issues. The practice of disposing a mixture of waste before treatment was reported to be expensive to municipalities in terms of collection, transportation and loss of valuable materials. The study reported that households were only interested in receiving effective dependable waste management services however, campaigns against negative impacts and inadequate waste collection influenced peoples' attitudes positively. The study concluded that detailed waste characteristics and variation is critical for waste management. Waste composition has effects to human health, environmental impacts and all processes of waste management from storage, collection, transport, choice of technology and its disposal. That to achieve successful waste management, it should be done at local levels instead of current large concentrated practice. Regardless of type of municipal waste composition, urban planning and waste management strategies, the government's initiative to make the necessary inputs is very important to translate SWM into reality. There is also need to involve the community as stakeholders and review legislation to streamline roles of all stakeholders and agencies involved in waste management.

Agwu (2012) carried out a study in Port Harcourt city Nigeria and assessed issues and challenges of SWM practices on behavioral perspective. The objective of the paper was to examine the relationship between individual background (age, sex, and social class) and their level of awareness, knowledge and practice on SWM. The study was guided by the research question that addressed the extent of relationship between individuals' background and the level of residents' awareness and practice on SWM. The research assumed that background of residents influenced their attitude and perceived behavioral control thus determined their actual behavior which included level of awareness, knowledge and their practices towards SWM. The study methodology was descriptive cross-sectional survey. The target population were residents of the city where a sample size of 800 were randomly surveyed using structured questionnaire. Data was analyzed by 
descriptive statistics. Study findings revealed that there was correlation between respondents' knowledge and practices on waste management which was consistent with previous studies by Jones and Raudsepp who documented on relationship between socio-demographic variables such as sex, age and education with environmental practices. Findings showed that more than half $(55.8 \%)$ of respondents expressed dissatisfaction on how solid waste was disposed, $33.2 \%$ were satisfied while only $10.9 \%$ were very satisfied with disposal of waste in their environment. From study findings, the research concluded that there was need for behavioral and attitude change to achieve solid waste reduction, recycling and reuse for sustainability. The study recommended that; there was need for sensitization of the city residents on dangers of poor SWM, provision of near accessible waste disposal points and incinerators, enactment of policies and laws concerning waste management practices with penalties to defenders and monitoring of waste recycling.

Okot- Okumu (2014) carried out a study in East African (EA) cities (Kenya, Uganda and Tanzania) to analyze SWM trends from the colonial time to the present. The research reported that the cities had moved from centrally controlled systems monopolized by the urban authorities to the current mixture where there are both public and private systems in varying combinations. The research established main challenges associated with the transition in SWM systems in EA cities and management of solid waste from the source to final disposal. The methodology used in the study was qualitative design which employed document analysis and observation as data collection instruments. The study reported that SWM system in EA has changed from colonial days (in 40s, 50s and 60s) when it was efficient because of lower urban population and adequate resources as compared to current status that displays inefficiencies. Much time is taken in collection and loading waste to trucks by council workers, in the process of transit the uncovered trucks litter the environment causing aesthetic problems. Introduction of private operators have increased solid waste collection levels compared to when it dependent entirely on council workers. In Tanzania and Uganda, it was reported that no formal and clear guidelines exist for e-waste disposal therefore more is generated. Kenya has developed guidelines for e-waste management even though rules are not adhered as it is handled by the informal sector. Composting is reported to be practiced in small scale across the three cities. Composting, recycling and biogas production was reported to be feasible options that would have social economic and environmental benefits to reduce the amount of waste disposed. All the EA countries have policy, legal and institutional framework for waste management. The study reported that the existing laws on waste management are not effectively enforced, informal sector operated with little or no regulation which was attributed to inherent weakness of the laws themselves. Inconsistent SWM services also included lack of political will, public commitment, lack of technical capacity and poor financing. The study recommended that an integrated approach to SWM involving a mix of centralized urban council, controlled conventional methods with innovative decentralized alternatives such as $3 \mathrm{R}$, composting, anaerobic biogas production can help to attain sustainability in SWM. For noted poor attitude of the public and political weakness towards SWM, it was suggested to adopt sustainable methods of waste management that were simple and accessible to change the mindset of residents to perceive waste as something of value.

\section{Discussion}

Reviewed literature focused on identifying challenges and weaknesses in SWM through application of VSM. Literature revealed that through value stream mapping, it is possible to generate a current state map that visually show flow of materials and information which could make it possible to identify weaknesses along the stream. The study validated the use of VSM as an appropriate tool to significantly improve processes in SWM. Literature revealed that involving all stakeholders in decision making and planning is key for implementation and that decision making and setting up programs depended on stakeholders' knowledge and familiarity with new appropriate technologies and good practices in SWM, however mostly lacking was knowledge, technology and good practice. Reviewed literature showed that improvement of physical infrastructure that included roads, equipment and human resource had a positive impact to SWM. That bad unpaved roads with poor road network and inadequate waste management facilities hindered waste management agencies to collect, transport and dispose generated waste adequately. Studies revealed that waste 
management processes, infrastructure and equipment be adequately funded and closely monitored for sustainability. Literature showed that detailed waste characteristics and variation is very important for waste management processes like; choice of technology, collection, transport, storage and disposal. And that regardless of waste composition, government's initiative to make the necessary inputs is very critical to achieve success in waste management. Reviewed literature showed that in most countries policies and laws were in place to steer the process however, there is inadequacy in law enforcement due to corruption, inadequate funding, citizens' attitude and lack of awareness among others. Literature showed that there was need for sensitization to positively change behavior and attitude of people. Other identified gaps included the design and methodology used. Some researchers used qualitative design thus presenting the results in verbalized reports, use of quantitative design presents a more elaborate report with quantitative illustrations. Some researchers relied on document analysis and observation as data collection instruments, document analysis may not give current information where records are not updated regularly. Some reviewed studies only included observation as the method of data collection. With observation as a data collection tool, there was possibility of more in-depth information left out (Creswell, 2013). In Guerrero (2013) study, the researcher targeted a very large area, with such a large area, findings of the study could only address general issues and leave out more pressing challenges in the various cities due to diversity in political and cultural factors.

Classifications of the VSM components (Consumer, Supplier, material flow and information flow) and their relationship to challenges of SWM (composition of solid waste, physical and technical infrastructure, policy legislation and enforcement, personnel, funding and community's attitude to SWM) is necessary to show linkages that different roles of VSM components play for a successful and sustainable SWM. Table 1.3 is a theoretical framework that conceptualizes the impact of each VSM component to the SWM challenges and overall performances attributed by the following key performance indicators; 1. Quality, 2. Cost, 3. 4. Health issues, 5. Time Management, 6. Efficiency, 7. Systems, 8. Awareness, 9. Environmental impact, 10. Job creation,

Table 1.3: Value Stream Mapping Components and their Impact on the Solid Waste Management Challenges

\begin{tabular}{|c|c|c|c|}
\hline $\begin{array}{l}\text { VSM } \\
\text { component }\end{array}$ & $\begin{array}{l}\text { SWM } \\
\text { Challenges }\end{array}$ & $\begin{array}{l}\text { Impact on SWM } \\
\text { challenges }\end{array}$ & References \\
\hline \multirow[t]{6}{*}{ Consumer } & Composition & $\begin{array}{l}\text { Quality; Health issues; Awareness; Environmental } \\
\text { impact }\end{array}$ & $\begin{array}{l}\text { Guerrero et al., 2013; Agwu, 2012; Rubiano } \\
\text { et al., 2014; Alexander et al., 2014; }\end{array}$ \\
\hline & \multirow{2}{*}{$\begin{array}{l}\text { Physical } \\
\text { \&Technical } \\
\text { infrastructure } \\
\text { Policy legislation } \\
\text { \& enforcement }\end{array}$} & $\begin{array}{l}\text { Time Management; Quality; Efficiency; Systems; } \\
\text { Environmental impact }\end{array}$ & \multirow{2}{*}{$\begin{array}{l}\text { Rubiano et al., 2014; Nabegu, 2010; } \\
\text { Guerrero et al., 2013; Alexander et al., } \\
\text { 2014; Agwu, 2012; Nitin et al., 2014. } \\
\text { Agwu, 2012; Okot-Okumu 2012; Alexander } \\
\text { et al., 2014; Shanmugam, 2015; Rubiano et } \\
\text { al., 2014; C } 40 \text { cities, 2016; Anura et al., } \\
\text { 2015; Moharana and Mcdonald, } 2014 \text {. }\end{array}$} \\
\hline & & $\begin{array}{l}\text { Efficiency; Time Management; Systems; Health } \\
\text { issues; Environmental impact }\end{array}$ & \\
\hline & Personnel & $\begin{array}{l}\text { Awareness; Efficiency; Time Management; Job } \\
\text { creation }\end{array}$ & $\begin{array}{l}\text { Nabegu, 2010; Rubiano et al., 2014; } \\
\text { Alexander et al., 2014; Agwu, 2012; Okot- } \\
\text { Okumu, 2012; Voltaire et al., } 2016 .\end{array}$ \\
\hline & Funding & $\begin{array}{l}\text { Cost; Efficiency; Systems; Environmental impact; } \\
\text { Job creation }\end{array}$ & $\begin{array}{l}\text { Alexander et al., 2014; Agwu, 2012; C } 40 \\
\text { Cities, 2016; Benefit et al., 2014; Moharana } \\
\text { and Mcdonald, } 2014 \text {. }\end{array}$ \\
\hline & $\begin{array}{l}\text { Community's } \\
\text { attitude }\end{array}$ & $\begin{array}{l}\text { Awareness; Environmental impact; Quality; Job } \\
\text { creation; Time Management }\end{array}$ & $\begin{array}{l}\text { Agwu, 2012; Rubiano, 2014; Okot-Okumu, } \\
\text { 2012; C } 40 \text { Cities, 2016; Anura et al., 2015; } \\
\text { C } 40 \text { cities, } 2016 .\end{array}$ \\
\hline \multirow[t]{3}{*}{ Supplier } & Composition & $\begin{array}{l}\text { Quality; Health issues; Cost; Efficiency; Systems; } \\
\text { Environmental impact }\end{array}$ & $\begin{array}{l}\text { Rubiano et al., 2014; Alexander et al., 2014; } \\
\text { Wangatia, 2014; Anura et al., 2015; Agwu, } \\
\text { 2012; Adedipe et al., } 2011 .\end{array}$ \\
\hline & \multirow{2}{*}{$\begin{array}{l}\text { Physical \& } \\
\text { Technical } \\
\text { infrastructure } \\
\text { Policy legislation } \\
\text { \& enforcement }\end{array}$} & $\begin{array}{l}\text { Efficiency; Quality; Time Management; } \\
\text { Environmental impact; Cost }\end{array}$ & \multirow{2}{*}{$\begin{array}{l}\text { Abreu \& Alves, 2015; Benefit et al., 2014; } \\
\text { Rubiano et al., 2014; Agwu, 2012; C } 40 \\
\text { Cities, 2016; } \\
\text { C } 40 \text { Cities, 2016; Okot-Okumu, 2014; } \\
\text { Josiane et al., 2015; Agwu, 2012; } \\
\text { Shanmugam, 2015; Voltaire et al., } 2016 .\end{array}$} \\
\hline & & $\begin{array}{l}\text { Systems; Efficiency; Time Management; Quality; } \\
\text { Health issues; Environmental impact }\end{array}$ & \\
\hline
\end{tabular}




\begin{tabular}{|c|c|c|}
\hline $\begin{array}{l}\text { VSM } \\
\text { component }\end{array}$ & $\begin{array}{l}\text { SWM } \\
\text { Challenges }\end{array}$ & $\begin{array}{l}\text { Impact on SWM } \\
\text { challenges }\end{array}$ \\
\hline & Personnel & $\begin{array}{l}\text { Cost; Efficiency; Time Management; Quality; } \\
\text { Systems; Job creation; Health issues }\end{array}$ \\
\hline & Funding & $\begin{array}{l}\text { Cost; Systems; Efficiency; Time Management; } \\
\text { Quality; Job creation; }\end{array}$ \\
\hline & $\begin{array}{l}\text { Community's } \\
\text { attitude }\end{array}$ & $\begin{array}{l}\text { Awareness; Quality; Job creation; Time } \\
\text { Management; Health issues; Environmental } \\
\text { impact }\end{array}$ \\
\hline $\begin{array}{l}\text { Material } \\
\text { flow }\end{array}$ & Composition & $\begin{array}{l}\text { Cost; Efficiency; Quality; Environmental impact; } \\
\text { Health issues; Job creation }\end{array}$ \\
\hline
\end{tabular}

flow

Physical \&

Technical infrastructure

Policy legislation

\& enforcement

Personnel

Funding

Community's attitude

Information Composition flow

Physical \&

Technical infrastructure Policy legislation \& enforcement

Personnel

Funding

Community's attitude
Efficiency; Time Management; Cost; Quality; Environmental impact; Systems; Job creation

Efficiency; Time Management; Health issues; Quality; Environmental impact; Systems; Job creation

Health issues; Quality; Time Management; Efficiency; Systems; Environmental impact; Awareness; Job creation

Cost; Efficiency; Systems; Time Management; Quality; Job creation; Environmental impact

Awareness; Quality; Job creation; Environmental impact; Health issues

Time Management; Efficiency; Health issues; Job creation; Awareness; Environmental impact

Efficiency; Time Management; Quality; Systems; Environmental impact; Systems

Efficiency; Time Management; Quality; Health issues; Job creation; Systems; Environmental impact

Efficiency; Time Management; Health issues; Awareness; Quality; Systems; Environmental impact

Efficiency; Time Management; Quality; Systems; Job creation; Environmental impact

Awareness; Quality, Job creation; Health issues; Environmental impact
References

Anura et al., 2015; Nabegu, 2010;

Alexander et al., 2014; Rubiano et al., 2014; Miezah et al., 2015; Moharana and Mcdonald, 2014.

Alexander et al., 2014; Rubiano et al., 2014; Adedipe et al., 2011; Guerrero et al., 2013; Nitin et al., 2014;

C 40 Cities, 2016; Agwu, 2012; Anura et al. 2015; Rubiano et al., 2014; Ramune and Milita, 2012; Okot and Nyenje, 2011;

Rubiano et al. 2014; Mieza et al., 2015; Abreu and Alves, 2015; C 40 Cities, 2016; Moharana and Mcdonald, 2014

Adedipe et al., 2011; Guerrero et al., 2013; Aura et al. 2015; Abreu and Alves, 2015; C 40 Cities, 2016:

Shanmugam, 2015, Okot-Okumu, 2012, Alexander et al, 2014; Agwu, 2012; Miezah et al., 2015.

Okot \& Nyenje, 2011; Nabegu, 2010;

Ribiano et al., 2014; Alexander et al., 2014; C 40 Cities, 2016. Wangatia, 2014.

Alexander et al., Rubiano et al., 2014;

Adedipe et al., 2011; Guerrero et al., 2013; C 40 Cities, 2016; Benefit et al., 2014.

Agwu, 2012; C 40 Cities, 2016; Anura et al. 2015; Okot \& Nyenje, 2011; Miezah et al., 2015; Voltaire et al., 2016;

Abreu and Alves, 2015; Ramune and Milita, 2012; Agwuoke and Orji, 2013; Adedipe et al., 2011;

Alexander et al., 2014; Guerrero et al., 2013; Adedipe et al., 2011; C 40 Cities, 2016

Anura et al. 2015; Okot \& Nyenje, 2011; Agwu, 2012; C 40 Cities, 2016; Guerrero et al., 2013;

Agwuoke and Orji, 2013; Adedipe et al., 2011; Guerrero et al., 2013; C 40 Cities, 2016; Anura et al. 2015.

Okot \& Nyenje, 2011; Alexander et al., 2014; Agwu, 2012; Shanmugam, 2015; Miezah et al., 2015; Nitin et al., 2014.

Agwu, 2012; C 40 Cities, 2016; Anura et al 2015; Okot \& Nyenje, 2011; Miezah et al., 2015.

\section{Conclusion}

Value stream mapping is an effective technique that can be used to reduce or eliminate waste in processes of solid waste management, mitigate challenges of SWM and identify opportunities for improvement. From the reviewed literature it is clear that policies and legislation are very necessary to plan, design and implement solid waste management operations, however with no enforcement the policies are toothless. Therefore, strict adherence and compliance to the policies is very important for sustainability. Empowering and involving all stakeholders in decision making is also critical for sustainability. Government's input and intervention to all the key mentioned challenges of solid waste management can significantly turn around the service delivery to global acceptable standards. 


\section{References}

Agwu M. O (2012). Issues and Challenges of Solid Waste Management Practices in Port Harcourt city, Nigeriaa Behavioural Perspective American Journal of Social and Management Sciences, 3(2), 83-87.

Alexander F. O., Kwame O. S. and Stephen O. (2014). Assessing the challenges affecting solid waste management system in the Kumasi Metropolis, Ghana. Journal of Arts and Humanities, 3 (2), 52-58

Abreu F. M and Alves C. A (2015). Lean Companies in the Track of Sustainability; $6^{\text {th }}$ International Conference on Mechanics and materials in Design. Recent Advances in Mechanics and Materials in Design- Paper ref: 5679.

Agwuoke M., and Orji E. (2013). Adding value to Municipal Waste in Nigeria through Mapping. Available at: http://www.fig.net/pub/fig2013/papers/ts01c/TS01C_michael-agwuoke_ekpete_6550.pdf , 4-8.

Adedipe N.O., Sridhar M.K.C., Baker J., Mathu V. (2010). Waste Management, Processing, and Detoxification. Ecosystems and Human Well-being: Policy Responses, 320-322.

Anura A., Samrit Y., Andy F. W., Siti R. (2015). Public Service Management in Local Government, Thailand. (Case Study of Solid Waste Management in Pattaya City. International Journal of Applied Sociology, 5(1), 9-13.

Benefit O. S. and Trevor (2014). Impact of inadequate urban planning on municipal solid waste management in the Niger Delta Region of Nigeria. Journal of Sustainable Development, 7(6), 27-36

Creswell J. W. (2014). Research design. Qualitative, Quantitative and Mixed Methods Approaches. $\left(4^{\text {th }}\right.$ Edition.). SAGE Publications. Thousand Oaks, California.

C 40 cities (2016). 'Good Practice Guide, Sustainable Solid Waste Systems' Climate leadership group. Available at: Http://www.c 40.org contact@c40.org, 4-7.

Guerrero L. A., Ger M and Hogland W., (2013). Solid waste management challenges for cities in developing countries: www.elsevier.com/locate/wasman: Waste Management, 33 (2013), 223-229

Josiane P., Kelly C., Fabiano L., Renato da Silva L., (2015). Urban Solid Waste Management by process mapping and simulation. Pesquisa. Operacional, . 35 (1).

Miezah K., Kwasi O. D., Zsofia K., Fei-Baffoe B., Mensah Y. M. (2015). Municipal solid waste characterization and quantification as a measure towards effective waste management in Ghana: Journal homepage: www.elsevier.com/locate/wasman, 46 (2015) 15-27

Moharana C., and Mcdonald C. (2014). Trends of Urban Solid Waste Management in Agartala City, Tripura, India. Universal Journal of Environmental Research and Technology, 4 (4) 227-235

Martin, K., \& Osterlin, M. (2013). The New Bible for Value Stream Mapping and Improving Organizational Performance. 'How to Visualize Work and Align Leadership for Organizational Transformation: e-ISBN 978-0-07-18284-9; e-MHID 0-07-182894-X. McGraw-Hill.

Nabegu A. B. (2010). An Analysis of Municipal Solid Waste in Kano Metropolis, Nigeria. J Hum Ecol, 31(2), 113-116.

Nitin M., Ravindra J., Bhalachandra D., (2014). Assessment of Municipal Solid Waste Management of Pune City using Geospatial Tools. International Journal of Computer Applications, 100 (10), 24-28.

Okot - Okumu J. (2014). Solid Waste Management in African Countries. Chapter 1. International Journal of Waste Management. Available at, https://www.researchgate.net/profile/James_Okot-Okumu/publications

Okot-Okumu, J., \& Nyenje. R., (2011). "Municipal solid waste management under decentralization in Uganda." Habitat International 35, 537543.

Rubiano O. Oscar, Pena M. Claudia C \& Paz R. Juan C., (2014). Solid Waste Management Applying Value Stream Mapping, A Small and Medium Enterprise Case. Available at; http://bibliotecadigital.univalle.edu.co/bitstream/10893/8362/1/05-A05-p43-50.pdf

Ramune C., Milita V. (2012). Lean Manufacturing: Theory and Practice. Economics and Management, 17(2), 726-730

Shanmugam L. (2015). 'A study on Minimization of Construction Waste Through Lean Construction Principles in Tirupur, Timilnadu'. International Journal of Advanced and Innovative Research, 4 (4), 289-290

Stevenson W. J. (2012). Operations management theory and practice. $\left(11^{\text {th }}\right.$ edition). McGraw Hill-Education (UK). Limited

Voltaire A., Johannes P., Crispian L., Emelita A., Maria Delia C. V., (2016). The 7th International Conference on Waste Management and Technology Development of the Philippines National Solid Waste Management Strategy 2012-2016. Available at: https://www.researchgate.net/publication/257728730

Wangatia M. V., (2014). Socioeconomic implications of solid waste management practices on participating households, Kenya. Community disaster interventions (CDI), Nairobi, Kenya. Available at: http://journals.jkuat.ac.ke/index.php/jscp/article/view/1083

Xiaogi L. (2014). A Literature Review on Value Stream Mapping with a Case Study of Applying Value Stream Mapping on Research Process. Available at: http://oaktrust.library.tamu.edu/bitstream/handle/1969.1/152791 